\title{
Czy największe gospodarki świata znajdują się w pułapce płynności?
}

Are the world's largest economies in liquidity trap?

\section{Wprowadzenie}

Porównując ewolucję realnego PKB na mieszkańca w Stanach Zjednoczonych, strefie euro i Japonii od 2008 r., można zauważyć, iż działania prorozwojowe w USA były znacznie bardziej skuteczne w pobudzaniu ożywienia gospodarczego niż w pozostałych, badanych gospodarkach. Jednak początkowa reakcja Europejskiego Banku Centralnego (Europen Central Bank - ECB) i Systemu Rezerwy Federalnej (Federal Reserve System - FED) w kwestii prowadzonej polityki pieniężnej była dość podobna. Ekspansja monetarna spowodowała, że na początku 2009 r. stopy procentowe we wspomnianych gospodarkach zbliżyły się do zera.

Początkowy pomysł był dość prosty. Poprzez zwiększenie nominalnej podaży pieniądza uczestnicy rynku posiadający nadwyżki finansowe mieli być zachęceni do zakupu obligacji rządowych. Rosnący na nie popyt miał spowodować wzrost ich cen, a tym samym spadek ich rentowności, stymulując konsumpcję i inwestycje poprzez tzw. efekt Keynesa. Jednakże przy stopach procentowych bliskich zeru gospodarki USA, strefy euro i Japonii stanęły w obliczu „pułapki płynności", zniechęcając uczestników rynku do zakupu obligacji.

Celem podjętych badań jest próba wersyfikacji empirycznej hipotezy pułapki płynności w trzech największych na świecie pod względem wytworzonego PKB, wysoko rozwiniętych gospodarkach (USA, strefa euro i Japonia) po kryzysie finansowym z $2008 \mathrm{r}$. W artykule wykorzystano metodę badawczą opartą na studiach literaturowych z zakresu makroekonomii i finansów oraz metody statystyczne. Wszystkie wykorzystane w pracy dane statystyczne pochodziły z urzędu 
statycznego Unii Europejskiej - EUROSTAT oraz z bazy statycznej Konferencji Narodów Zjednoczonych do spraw Handlu i Rozwoju - UNCTADSTAT.

\section{Istota i przyczyny pułapki płynności}

W literaturze ekonomicznej istnieją co najmniej cztery różne definicje pułapki płynności, sformułowane przez znanych, światowych ekonomistów. Według Ecclesa pułapka płynności to sytuacja, w której ekspansywne, otwarte rynki przyczyniają się do akumulacji nadwyżek rezerw finansowych w bankach komercyjnych. Nadwyżka rezerw finansowych może wynikać z faktu, że nawet przy niskiej stopie procentowej, gdy perspektywy rozwoju gospodarki są pesymistyczne, przedsiębiorstwa mogą nie być zainteresowane w danym momencie dalszą ekspansją, a banki komercyjne ponoszeniem większego ryzyka związanego z udzielaniem kredytów (Moe, Marriner 2013).

Z kolei według Keynesa (1936) pułapka płynności to sytuacja, w której inwestorzy są gotowi przy bardzo niewielkiej zachęcie cenowej zastąpić długoterminowe obligacje gotówką. Powodem takiej sytuacji jest to, że uczestnicy rynku uważają, iż ceny obligacji osiągnęły swój szczyt. Innymi słowy, istnieje przeświadczenie, że długoterminowe stopy procentowe osiągnęły już swoje minima.

Natomiast pułapka płynności według koncepcji Hicksa (1937) opiera się na jego modelu IS-LM. Zgodnie z jego poglądami przy niskich stopach procentowych popyt na pieniądz może być doskonale elastyczny, a pieniądz i obligacje długoterminowe są idealnymi substytutami. Pułapka płynności Hicksa oznacza, że gdyby centralne władze monetarne próbowały podnieść stopę procentową poprzez sprzedaż obligacji na otwartym rynku, to działania takie zakończyłyby się niepowodzeniem. Posiadacze oszczędności zmniejszyliby swoje zasoby pieniężne przy niewielkiej zachęcie cenowej.

Wreszcie koncepcja pułapki płynności według Krugmana (1998) jest identyczna z koncepcją pułapki płynności Hicksa z tym wyjątkiem, że w pierwszym przypadku uwzględniana jest krótkoterminowa, a nie długoterminowa stopa procentowa. Jeśli założy się, że struktura terminowa stóp procentowych ma charakter egzogeniczny, to koncepcje Krugmana i Hicksa są takie same.

W przypadku, kiedy stopy procentowe są bliskie zeru, zwiększenie podaży pieniądza (przesunięcie krzywej LM do położenia LM') nie prowadzi do spadku stóp procentowych (i), a w efekcie do wzrostu popytu finansowanego z kredytów. 
Rysunek 1. Pułapka płynności

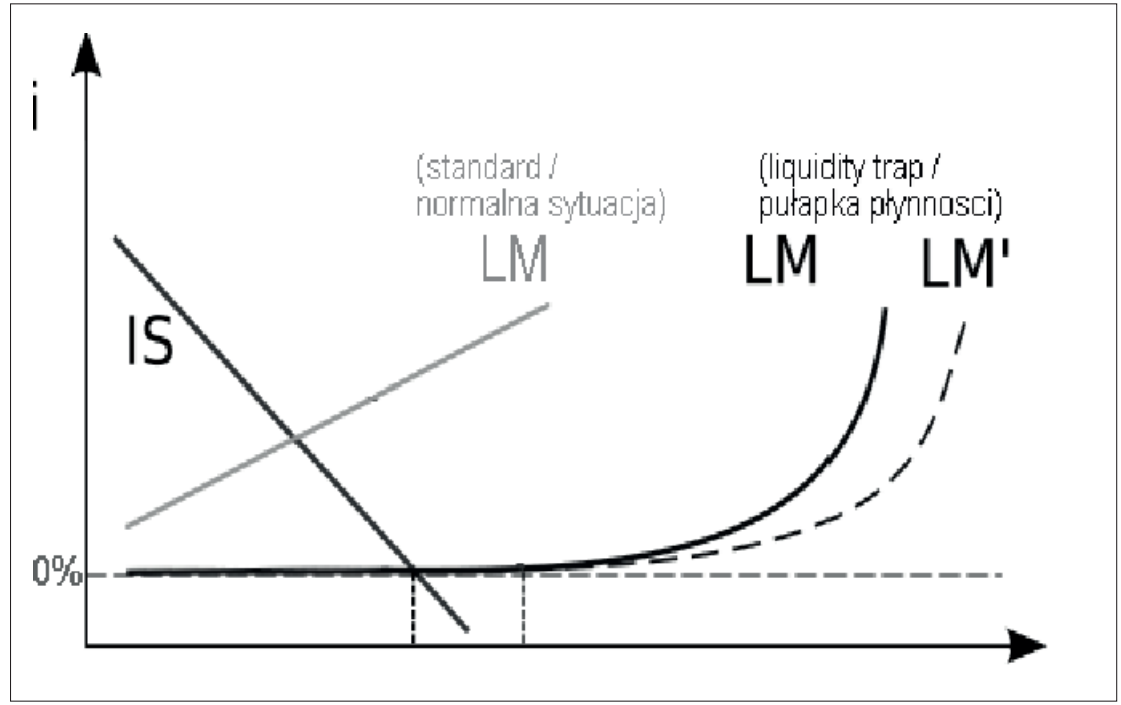

Źródło: opracowanie własne na podstawie Druk pieniądza (2012).

Zatem w tej sytuacji podaż pieniądza na rynku finansowym jest większa od popytu na pieniądz, związanego z potrzebą finansowania wydatków inwestycyjnych i konsumpcyjnych. Stąd w sytuacji niepełnego wykorzystania mocy produkcyjnych w gospodarce popyt na kredyt inwestycyjny spada, a konsumenci w obawie przed bezrobociem ograniczają skłonność do zaciągania kredytów konsumpcyjnych. Zatem, aby skłonić uczestników rynku do kredytowania konsumpcji i inwestycji, realne stopy procentowe oferowane na rynku pieniężnym musiałyby być ujemne.

Nieco inne przyczyny pojawienia się pułapki płynności wskazuje Koo (2011), nawiązując do tzw. koncepcji recesji bilansowej (balance sheet recession). Mianowicie, recesja bilansowa ma miejsce po pęknięciu bańki cenowej na rynku aktywów, kiedy wartość zobowiązań (długów) przekracza wartość aktywów, co prowadzi do ujemnej wartości netto tych aktywów. Jeśli nadal występują w gospodarce przepływy pieniężne, wówczas sektor prywatny, czyli przedsiębiorstwa i gospodarstwa domowe, wykorzystuje te fundusze, aby zaoszczędzić środki i spłacić dług, zamiast zaciągać pożyczki na inwestycje.

W konsekwencji popyt na pożyczone fundusze spada nawet przy bardzo niskich stopach procentowych, które w rzeczywistości nie stymulują zagregowanego popytu i inwestycji. Przy braku odpowiedniej reakcji ze strony rządu prawdopodobną konsekwencją tej sytuacji będzie deflacja długu i poważna recesja z masowym bezrobociem włącznie. Podczas gdy w czasie tzw. „normal- 
nej" recesji większość przedsiębiorstw maksymalizuje swoje zyski, to w sytuacji recesji bilansowej przedsiębiorstwa minimalizują swoje zadłużenie. Może ona wywołać niechęć sektora prywatnego do zaciągania pożyczek, co może trwać wiele lat, nawet po całkowitej spłacie zadłużenia. Stąd w powyższej sytuacji jedynym środkiem zaradczym, pozwalającym na wyjście kraju z recesji bilansowej i pułapki płynności, jest ekspansywna polityka fiskalna, ponieważ polityka pieniężna w tym przypadku okazuje się nieskuteczna.

\section{Pułapka płynności w świetle wyników wybranych analiz empirycznych}

W ostatnich latach przeprowadzono wiele badań dotyczących pułapki płynności, aby zweryfikować teoretyczne analizy z praktyką gospodarczą. Tobin (1975) udowodnił, że istnieje pułapka płynności, ponieważ krzywa popytu na tzw. wolny pieniądz wzrasta wraz ze spadkiem stopy procentowej, ale tylko do pewnego poziomu. Jednakże wyniki badań Tobina nie pozwoliły na jednoznaczne stwierdzenie występowania pułapki płynności w praktyce. Głównym ograniczeniem w badaniu Tobina (1975) było to, że nie uwzględniał on wpływu całkowitego bogactwa na preferencje społeczeństwa w zakresie płynności.

W warunkach standardowej polityki pieniężnej ograniczonej przez pułapkę płynności istotną rolę $\mathrm{w}$ gospodarce $\mathrm{w}$ celu pobudzenia popytu wewnętrznego odgrywa ekspansja fiskalna. Orphanides (2017) twierdzi, że stosunkowo szybka i odbywająca się na dużą skalę ekspansja fiskalna w USA była kluczowym czynnikiem determinującym późniejsze ożywienie gospodarcze w tym kraju, podczas gdy ekspansja fiskalna w strefie euro była znacznie mniejsza i nie doprowadziła w rezultacie do istotnego ożywienia gospodarczego w krajach członkowskich. Orphanides (2017) zaauważa także, że przy braku skutecznych instrumentów ją koordynujących wśród państw członkowskich strefy euro ogólna polityka fiskalna w strefie euro odzwierciedla jedynie agregację autonomicznych polityk fiskalnych poszczególnych państw członkowskich tego obszaru.

Ten pogląd wydaje się zbieżny z opiniami sformułowanymi przez Blancharda i innych (2015), którzy analizowali skutki ekspansji fiskalnej w podstawowych gospodarkach strefy euro w porównaniu z jej efektami w USA. Otóż autorzy badania twierdzą, że w przeciwieństwie do USA strefa euro nie jest unią fiskalną, stąd ekspansja fiskalna może być jedynie prowadzona samodzielnie przez poszczególne państwa członkowskie. Blanchard i inni (2016) formułują opinie, że chociaż gospodarki peryferyjne w strefie euro częściej wykorzystują ekspansję 
fiskalną, to jednak możliwości te są istotnie ograniczone z powodu istniejącego długu publicznego i problemów z wypłacalnością. Dlatego też ekspansja fiskalna musi być wywołana przez główne (dominujące) gospodarki strefy euro, określane mianem krajów tzw. rdzenia gospodarczego. Dodatkowo Blanchard i inni (2015) uważają, że przy braku pułapki płynności wyższe wydatki rządowe w gospodarkach dominujących mają niewielki lub nawet negatywny wpływ na PKB w krajach peryferyjnych.

Jednak biorąc pod uwagę fakt, że obecna polityka pieniężna w strefie euro nie prowadzi do wzrostu stóp procentowych, okazuje się, że PKB w krajach peryferyjnych ma tendencję wzrostową w odpowiedzi na ekspansję budżetową w krajach tzw. rdzenia strefy euro. W tych warunkach wyższe wydatki publiczne mogą zwiększyć inflację zarówno w gospodarkach dominujących, jak i w krajach peryferyjnych. Sytuacja ta prowadzi tym samym do obniżki realnych stóp procentowych. Autorzy badania twierdzą również, że wzrost wydatków rządowych w gospodarkach dominujących o 1\% PKB całej strefy euro zwiększył PKB w krajach peryferyjnych o ok. $1 \% \mathrm{w}$ okresie ostatnich trzech lat, powodując jednocześnie znaczący wzrost dobrobytu w całej strefie euro. Badania ujawniają, że efekty w postaci polepszenia dobrobytu są jednak mniejsze, niż mogłyby być w ramach pełnej unii fiskalnej, ponieważ w niej ekspansja budżetowa mogłaby mieć miejsce we wszystkich gospodarkach strefy euro, w tym w krajach peryferyjnych.

Z kolei Thirion (2017) twierdzi, że każdy mechanizm ubezpieczeń fiskalnych może prowadzić do różnorodnych zakłóceń na poziomie poszczególnych państw członkowskich, zwracając uwagę, że może to być szczególnie dotkliwe, jeżeli mechanizm ubezpieczeń fiskalnych umożliwia stałą redystrybucję dochodu między państwami członkowskimi. W szczególności argumentuje on, że w tej sytuacji rządy poszczególnych krajów mogą być zachęcane do unikania wdrażania niepopularnych reform strukturalnych lub do zwiększania długu publicznego, mając świadomość solidarnej i wspólnej odpowiedzialności wszystkich krajów członkowskich za długi pojedynczych gospodarek.

Aby pokonać pokusę nadużycia wynikającą ze wspomnianego, swoistego mechanizmu ubezpieczeń fiskalnych, Vandenbroucke i inni (2016) opowiadają się za przeniesieniem odpowiednich kompetencji fiskalnych z poziomu krajowego na centralny, co oznacza częściową utratę suwerenności fiskalnej krajów członkowskich. Wówczas w przypadku problemów budżetowych w danym kraju nie byłoby zgody na cięcia wydatków, np. na edukację czy badania naukowe i rozwój, ponieważ takie działania mogłyby pogorszyć długoterminową konkurencyjność danego kraju. Vandenbroucke i inni (2016) argumentują, że taka 
centralna instancja powinna mieć przynajmniej prawo weta, aby zapobiec takim niepożądanym działaniom na poziomie poszczególnych państw członkowskich.

\section{Sytuacja gospodarcza w USA, strefie euro i Japonii a putapka płynności}

Od stycznia 2008 r. do grudnia 2013 r. bilans FED wzrósł o ok. 3,5 bln USD z powodu realizowanej przez bank centralny polityki skupu aktywów finansowych na dużą skalę (Large Scale Asset Purchase), wdrożonej w celu pomocy gospodarce amerykańskiej po kryzysie finansowym. Ta niekonwencjonalna polityka pieniężna, zwana również luzowaniem ilościowym (Quantitative Easing), zwiększyła dostępność kredytów na rynkach finansowych i wywarła presję na obniżkę realnych stóp procentowych (Rosati, 2016).

W tzw. normalnych czasach, czyli w okresie przedkryzysowym w USA, dla każdego 1-procentowego wzrostu podaży pieniądza inflacja wzrastała o 0,54\% (Arias, Wen, 2014). Z kolei w okresie po wystąpieniu kryzysu finansowego podaż pieniądza (M0) wzrosła w USA o 40,29\% między grudniem 2008 r. a grudniem 2013 r., czyli średnio o ok. 8\% rocznie. Przy takim tempie rocznego wzrostu podaży pieniądza roczna stopa inflacji powinna wzrosnąć do 4,3\%, co oznaczałoby podniesienie poziomu cen w gospodarce amerykańskiej o ok. $40 \% \mathrm{w}$ okresie 2008-2013. Jednakże tak się nie stało. Pomimo istotnego zastrzyku 3,5 tryliona dolarów w gospodarkę USA nie spowodowało to znaczącego wzrostu inflacji. Polityka FED polegająca na ustaleniu dodatnich stóp procentowych od rezerw banków komercyjnych w banku centralnym jedynie spotęgowała wspomniany problem, czyniąc gotówkę bardziej atrakcyjną jako sposób przechowywania wartości. Po stosunkowo długim czasie kształtowania się stóp procentowych na zerowym poziomie, czyli po okresie supertaniego pieniądza, przyczyniającego się do wzrostu konsumpcji i inwestycji, FED rozpoczęła w 2016 r. proces podnoszenia stóp procentowych $\mathrm{w}$ odpowiedzi na rosnącą presję inflacyjną. $\mathrm{O}$ ile efektywna stopa procentowa w 2016 r. wynosiła $0,4 \%$ to w 2018 r. sięgnęła już 1,7\%. Oznaczało to wzrost o 325\%. Dla porównania, przed kryzysem w 2008 r. efektywne stopy procentowe wzrosły z 1 aż do 5,24\%, czyli o 424\%. 
Rysunek 2. Stopa inflacji i stopa procentowa* w USA w okresie 2008-2018 [w \%]

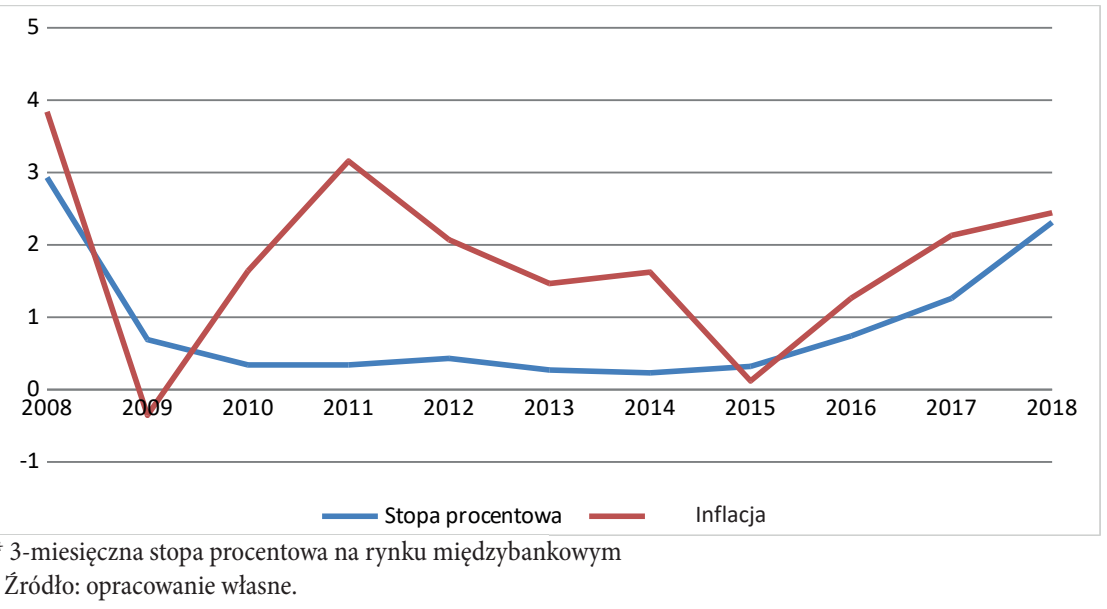

Na podstawie danych przedstawionych na powyższym rysunku można zauważyć, iż niemalże w całym badanym okresie realna stopa procentowa w USA (nominalna stopa procentowa pomniejszona o stopę inflacji) była ujemna. Wyjątek stanowiły tylko lata $2009 \mathrm{i} 2015$, kiedy realna stopa procentowa była dodatnia.

Jednocześnie należy zauważyć, że w okresie 2008-2018, pomimo znacznych wahań stóp procentowych i inflacji w USA, wydatki konsumpcyjne gospodarstw domowych oraz wydatki inwestycyjne przedsiębiorstw systematycznie rosły z wyjątkiem okresu 2008-2009, kiedy odnotowano spadek wydatków konsumpcyjnych i inwestycyjnych w USA. Na koniec 2018 r. wydatki konsumpcyjne były wyższe o ponad 33\% w stosunku do 2008 r., wydatki inwestycyjne zaś były wyższe w stosunku do 2008 r. o ponad 27\%. Tym samym, dzięki ujemnym realnym stopom procentowym gospodarka amerykańska zdołała wydostać się z pułapki płynności. 
Rysunek 3. Wydatki konsumpcyjne i inwestycyjne w USA w okresie 2008-2018 [w mln USD]

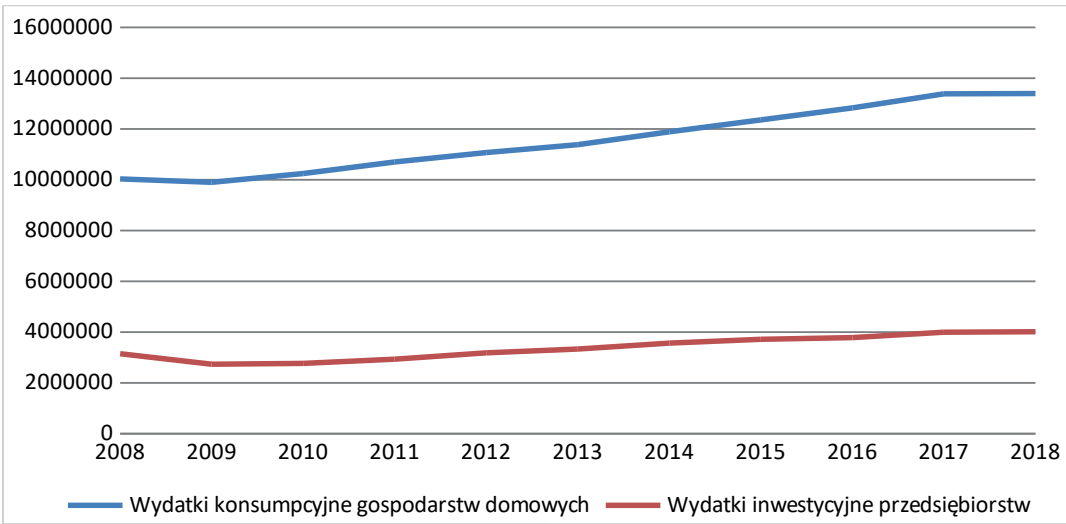

Źródło: opracowanie własne.

Z kolei ECB długo wstrzymywał się przed pójściem śladami FED i Banku Centralnego Japonii. Wykorzystywał inne instrumenty niestandardowej polityki pieniężnej. Od końca 2008 r. do połowy 2009 r. obniżył stopy procentowe z 4,25\% do 1\%, a w 2016 r. zredukował je do historycznie najniższego poziomu równego zero. Co więcej, stopa depozytowa ECB została ustalona na ujemnym poziomie, co miało zniechęcić banki komercyjne do utrzymywania pieniędzy na rachunkach w banku centralnym.

Jednocześnie ECB umożliwił bankom komercyjnym zaciąganie tanich kredytów o oprocentowaniu równym $1 \%$ w ramach tzw. ukierunkowanych, dłuższych operacji refinansujących (long term refinancing operations). Banki komercyjne miały możliwość wykorzystania tych środków w celu zwiększania akcji kredytowej lub nabywania rządowych obligacji, obniżając ich oprocentowanie. Ponadto w maju 2009 r. ECB ogłosił program skupu obligacji zabezpieczonych hipoteką, a w 2010 r. zaczął sukcesywnie nabywać na rynku wtórnym obligacje rządowe w ramach tzw. Programu Rynków Papierów Wartościowych. Wszystkie wspomniane powyżej działania ECB doprowadziły do istotnej obniżki kosztów obsługi długu.

Jednakże dotychczasowa intensywność i zakres interwencji ECB były znacznie mniejsze niż w przypadku FED i Banku Centralnego Japonii. W 2015 r. ECB zapoczątkował realizację polityki luzowania ilościowego, kupując obligacje komercyjne i rządowe, początkowo na kwotę 60 mld euro miesięcznie, potem zwiększając te zakupy do 80 mld euro miesięcznie. ECB rozpoczął skup obligacji kilka miesięcy po tym, jak FED zakończył podobne operacje. ECB wciąż utrzymuje stopy procentowe na rekordowo niskim poziomie, zapowiadając jednocześnie zakończenie procesu skupu obligacji. 
Rysunek 4. Stopa inflacji i stopa procentowa* w strefie euro w okresie 2008-2018 [w \%]

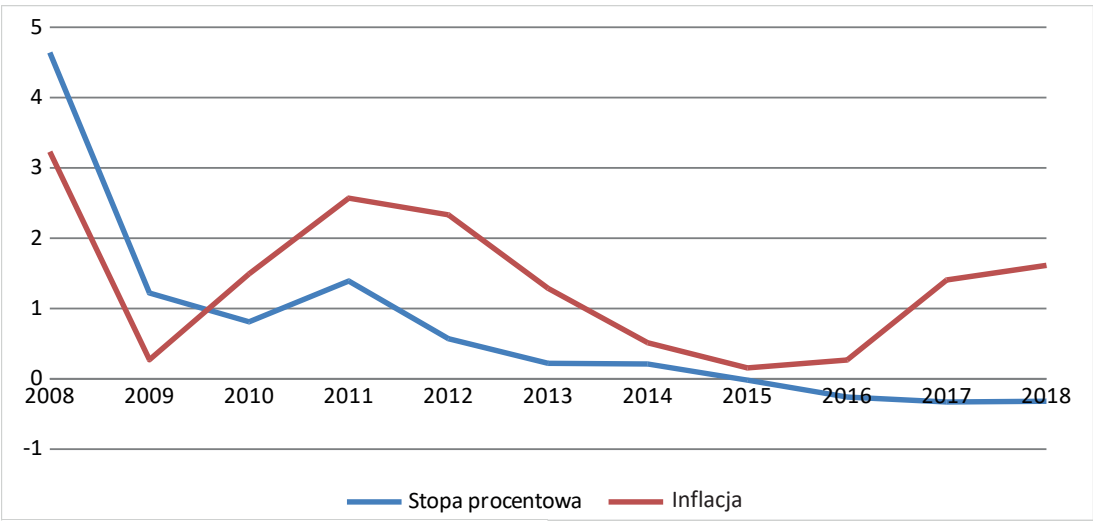

* 3-miesięczna stopa procentowa na rynku międzybankowym Źródło: opracowanie własne.

W strefie euro, podobnie zresztą jak w gospodarce amerykańskiej, realna stopa procentowa była ujemna w badanym okresie z wyjątkiem lat 2008-2009, kiedy odnotowano dodatnią, realną stopę procentową. Co więcej, można dostrzec, iż ujemna, realna stopa procentowa, pomimo tendencji spadkowej, obserwowanej w okresie 2012-2015, ponownie wzrasta od $2016 \mathrm{r}$.

Pomimo niskich nominalnych stóp procentowych oraz ujemnych realnych stóp procentowych w strefie euro uczestnicy rynku nie zwiększają znacząco wydatków konsumpcyjnych i inwestycyjnych. W porównaniu z 2008 r. wydatki konsumpcyjne gospodarstw domowych spadły w 2018 r. o ok. 11\%, a wydatki inwestycyjne przedsiębiorstw obniżyły się o blisko $20 \%$. W tej sytuacji bank centralny nie posiada zbyt dużych możliwości pobudzenia gospodarki, ponieważ nie ma odpowiedniej reakcji po stronie popytu. Zatem można stwierdzić, iż gospodarka strefy euro znajduje się obecnie właśnie w pułapce płynności. Co więcej, jeśli wspomniana sytuacja będzie trwała stosunkowo długo, może to w konsekwencji doprowadzić do pojawienia się deflacji. 
18 | Przegląd Prawno-Ekonomiczny

Rysunek 5. Wydatki konsumpcyjne i inwestycyjne w strefie euro w okresie 2008-2018 [w mln USD]

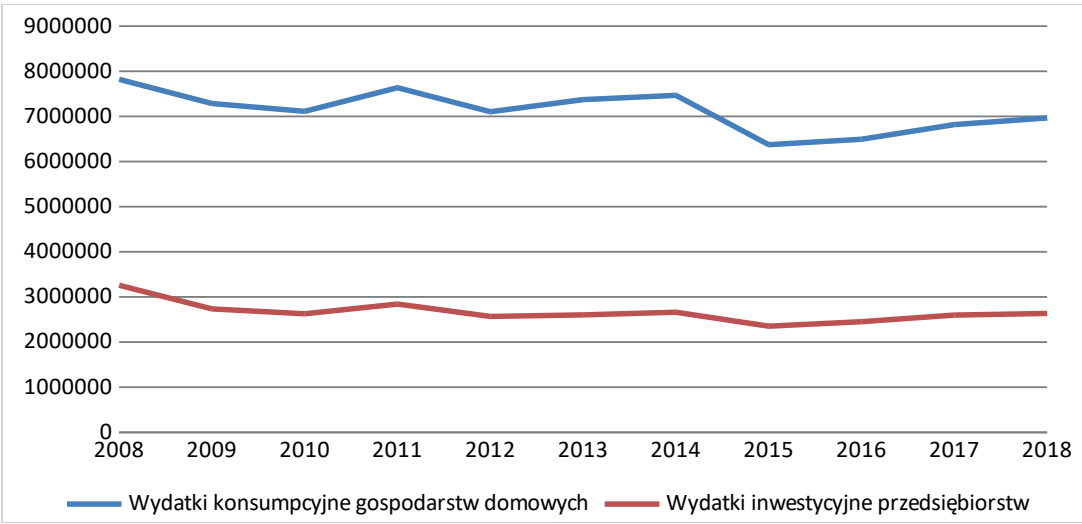

Źródło: opracowanie własne.

Również japońska gospodarka stanowi dobry przykład kraju, który wpadł w pułapkę płynności. Samo zwiększenie bazy monetarnej wyniku polityki luzowania ilościowego nie przyczyniło się do wzrostu pozostałych agregatów pieniężnych i nie spowodowało wyraźnego wzrostu inflacji oraz oczekiwanego poziomu cen. Gospodarstwa domowe i przedsiębiorstwa w dalszym ciągu nie postrzegały ekspansji monetarnej jako trwałego zjawiska. Realna stopa procentowa w Japonii w zasadzie od 2008 r. do 2012 r. była dodatnia za sprawą deflacji, natomiast od 2013 r. jest ujemna na skutek pojawienia się inflacji w tym kraju (Frejtag-Mika, 2014).

Rysunek 6. Stopa inflacji i stopa procentowa* w Japonii w okresie 2008-2018 [w \%]

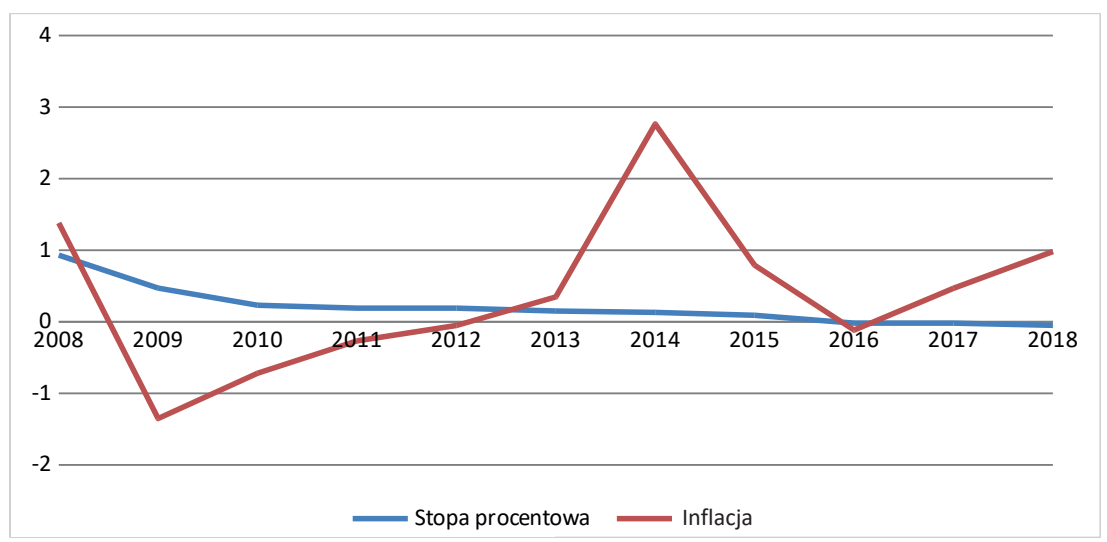

*3-miesięczna stopa procentowa na rynku międzybankowym

Źródło: opracowanie własne. 
Jednakże ekspansywne działania podjęte przez bank centralny oraz rząd Japonii, zwiększający wydatki budżetowe, okazują się nieskuteczne, aby wyjść z pułapki płynności. Społeczeństwo oczekuje niskiego tempa wzrostu cen, więc nie ma odpowiedniej motywacji do zwiększenia konsumpcji. Brak dostatecznie rosnącego popytu sprawia, iż przedsiębiorstwa nie zwiększają produkcji i zatrudnienia. W tych warunkach również inwestycje pozostają stabilne. Na koniec 2018 r. wydatki konsumpcyjne gospodarstw domowych obniżyły się w stosunku do 2008 r. o ok. 6\%, podczas gdy wydatki inwestycyjne przedsiębiorstw spadły o ponad $3 \%$.

Rysunek 7. Wydatki konsumpcyjne i inwestycyjne w Japonii w okresie 2008-2018 [w mln USD]

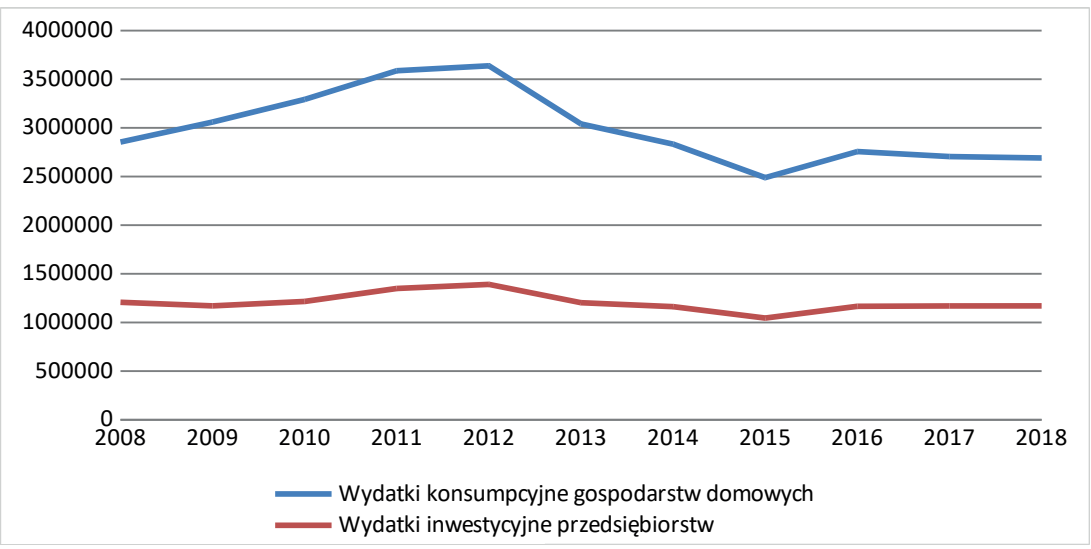

Źródło: opracowanie własne.

Równocześnie rząd Japonii wprowadził gwarancję dożywotniego zatrudnienia, co doprowadziło do spadku produktywności w kraju. Ponadto system keiretsu przyznaje niejako producentom monopolistyczną pozycję na rynku. Zmniejsza to siły wolnego rynku i innowacje w gospodarce. Japońskie społeczeństwo starzeje się, a rząd prowadzi restrykcyjną politykę imigracyjną. Dopóki te ograniczenia wzrostu nie zostaną wyeliminowane, Japonia pozostanie w pułapce płynności.

W rezultacie prowadzonej polityki gospodarczej, ukierunkowanej na przyspieszenie wzrostu gospodarczego w Japonii i walkę z deflacją, bank centralny tego państwa zdecydował się na znaczne zwiększenie podaży pieniądza w wyniku prowadzonej polityki luzowania ilościowego. Równocześnie rząd Japonii rozpoczął realizację nowej strategii wzrostu gospodarczego, obejmującej reformy strukturalne w zakresie rynku pracy, ochrony zdrowia, ułatwienia obrotu ziemią na cele inwestycyjne, deregulację sektora usług i zmiany w nadzorze właścicielskim (The Economist 2013 cyt. za: Frejtag-Mika 2014). 
Obliczone współczynniki korelacji między zmianą realnej stopy procentowej oraz zmianą wydatków konsumpcyjnych gospodarstw domowych w USA, strefie euro i Japonii potwierdzają fakt występowania stosunkowo niskiej zależności liniowej między wspomnianymi zmiennymi we wszystkich z badanych krajów. Największy współczynnik korelacji występował przy tym w Japonii, najniższy zaś w USA. Podobna sytuacja miała miejsce w przypadku współczynnika korelacji między zmianą realnej stopy procentowej i zmianą wydatków inwestycyjnych przedsiębiorstw w USA, strefie euro i Japonii. Również w tym przypadku potwierdzono występowanie niskiej zależności liniowej między badanymi zmiennymi, przy czym największy współczynnik korelacji miał miejsce w strefie euro, najniższy zaś w USA.

Tabela 1. Wartości bezwzględne współczynników korelacji między zmianą realnej stopy procentowej oraz zmianą wydatków konsumpcyjnych i inwestycyjnych w USA, strefie euro i Japonii

\begin{tabular}{|c|c|}
\hline \multicolumn{2}{|c|}{ USA } \\
\hline & zmiana stopy procentowej \\
\hline zmiana wydatków konsumpcyjnch & 0,05 \\
\hline zmiana wydatków inwestycyjnych & 0,10 \\
\hline \multicolumn{2}{|c|}{ strefa euro } \\
\hline \multicolumn{2}{|c|}{ Japonia } \\
\hline zmiana wydatków konsumpcyjnch & 0,30 \\
\hline zmiana wydatków inwestycyjnych & 0,54 \\
\hline \multicolumn{2}{|c|}{ zmiana stopy procentowej } \\
\hline zmiana wydatków konsumpcyjnych & 0,45 \\
\hline zmiana wydatków inwestycyjnych & 0,29 \\
\hline
\end{tabular}

Poziom istotności $\alpha=0,05$.

Źródło: opracowanie własne.

Z kolei poniżej dokonano analizy zależności przyczynowo-skutkowych między zmianą realnej stopy procentowej oraz zmianami wydatków konsumpcyjnych gospodarstw domowych i wydatków inwestycyjnych przedsiębiorstw w USA, strefie euro i Japonii za pomocą klasycznej metody najmniejszych kwadratów (Least Squares Method). Oszacowano dwa poniższe równania:

(1) $C \_\operatorname{Exp}_{t}=a+\beta R I R_{t}+\varepsilon_{t}$ 
(2) $I_{-} \operatorname{Exp}_{t}=a+\gamma R I R_{t}+\varepsilon_{t}$

gdzie:

$a$ - wyrażenie wolne równania;

C_Exp - zmiana wydatków konsumpcyjnych gospodarstw domowych;

I_Exp - zmiana wydatków inwestycyjnych przedsiębiorstw;

$R I R$ - zmiana realnej stopy procentowej;

$\beta, \gamma$ - współczynniki elastyczności;

$\varepsilon$ - składnik losowy;

$t$ - okres analizy.

Tabela 2. Współczynnik oddziaływania zmian realnej stopy procentowej na zmiany wydatków konsumpcyjnych oraz inwestycyjnych w USA, strefie euro i Japonii

\begin{tabular}{|c|c|c|c|}
\hline \multicolumn{4}{|c|}{ USA } \\
\hline wyszczególnienie & $\begin{array}{l}\text { współczynnik oddziały- } \\
\text { wania zmian realnej stopy } \\
\text { procentowej }\end{array}$ & błąd standardowy & statystyka-t \\
\hline $\begin{array}{l}\text { zmiana wydatków } \\
\text { konsumpcyjnych }\end{array}$ & $-0,010306$ & 0,066604 & $-0,154741$ \\
\hline $\begin{array}{l}\text { zmiana wydatków } \\
\text { inwestycyjnych }\end{array}$ & $-0,035057$ & 0,010004 & $-3,504386$ \\
\hline \multicolumn{4}{|c|}{ strefa euro } \\
\hline wyszczególnienie & $\begin{array}{l}\text { współczynnik oddziały- } \\
\text { wania zmian realnej stopy } \\
\text { procentowej }\end{array}$ & błąd standardowy & statystyka-t \\
\hline $\begin{array}{l}\text { zmiana wydatków } \\
\text { konsumpcyjnych }\end{array}$ & $-0,012222$ & 0,015696 & $-0,778687$ \\
\hline $\begin{array}{l}\text { zmiana wydatków } \\
\text { inwestycyjnych }\end{array}$ & $-0,010306$ & 0,066604 & $-0,154741$ \\
\hline \multicolumn{4}{|c|}{ Japonia } \\
\hline wyszczególnienie & $\begin{array}{l}\text { współczynnik oddziały- } \\
\text { wania zmian realnej stopy } \\
\text { procentowej }\end{array}$ & błąd standardowy & statystyka-t \\
\hline $\begin{array}{l}\text { zmiana wydatków } \\
\text { konsumpcyjnych }\end{array}$ & 0,041992 & 0,020022 & 2,097273 \\
\hline $\begin{array}{l}\text { zmiana wydatków } \\
\text { inwestycyjnych }\end{array}$ & 0,018309 & 0,020032 & 0,913995 \\
\hline
\end{tabular}

Poziom istotności $\alpha=0,05$.

Źródło: opracowanie własne za pomocą programu EViews. 
Obliczony współczynnik oddziaływania zmian realnych stóp procentowych na zmiany wydatków konsumpcyjnych gospodarstw domowych w USA był statystycznie nieistotny. Z kolei współczynnik oddziaływania zmiany realnej stopy procentowej na wydatki inwestycyjne był statystycznie istotny, lecz wyniósł niespełna $-0,03$, co świadczyło w zasadzie o braku istotnej reakcji zmiany wydatków inwestycyjnych przedsiębiorstw na zmiany stóp procentowych w tym kraju. Natomiast w strefie euro obliczone współczynniki oddziaływania zmiany realnej stopy procentowej na zmiany wydatków konsumpcyjnych gospodarstw domowych i wydatków inwestycyjnych przedsiębiorstw były statystycznie nieistotne. W przypadku Japonii współczynnik odziaływania zmiany realnej stopy procentowej na zmiany wydatków konsumpcyjnych był statystycznie istotny i wyniósł niespełna 0,04 , co wskazywało w zasadzie na brak wpływu zmian stóp procentowych na wspomniane zmiany wydatków gospodarstw domowych. Natomiast współczynnik oddziaływania zmiany realnych stóp procentowych na zmiany wydatków inwestycyjnych przedsiębiorstw w Japonii był statystycznie nieistotny. Tym samym wyniki powyższej analizy wskazywały w zasadzie na brak istotnej reakcji po stronie zmian wydatków konsumpcyjnych gospodarstw domowych oraz zmian wydatków inwestycyjnych przedsiębiorstw na zmiany realnych stóp procentowych w USA, strefie euro oraz Japonii w okresie 1998-2018.

\section{Sposoby wyjścia strefy euro z pułapki płynności}

Zgodnie z tzw. głównym nurtem ekonomii im większa podaż pieniądza, tym wyższy poziom inflacji, ponieważ więcej pieniędzy przypada na taką samą ilość dostępnych dóbr. Jednak w okresie pułapki płynności wzrost podaży pieniądza jest w pełni absorbowany przez nadmierny popyt na pieniądz (płynność). Uczestnicy rynku gromadzą pieniądze zamiast je wydawać, ponieważ koszt alternatywny posiadania gotówki w postaci utraconych zysków odsetkowych wynosi zero, gdy nominalna stopa procentowa jest równa zero (Stabilność cen, b.d.).

Z jednej strony, jeśli wzrost popytu na pieniądz jest proporcjonalny do wzrostu podaży pieniądza, inflacja pozostaje stabilna. $Z$ drugiej strony, jeśli popyt na pieniądz rośnie bardziej niż proporcjonalnie w stosunku do zmiany podaży pieniądza z powodu realizowanej polityki luzowania ilościowego wywierającej presję spadkową na stopę procentową, poziom cen w kraju musi spaść, aby zaabsorbować różnicę między podażą pieniądza i popytem na pieniądz. Dlatego im niższa stopa procentowa jako rezultat prowadzonej polityki luzowania 
ilościowego, tym niższy poziom cen (z powodu nieproporcjonalnie wyższego popytu na pieniądz).

Nie tylko wysoka, ale i niska inflacja może być szkodliwa dla gospodarki. Niska inflacja powoduje, że gotówka jest bardziej atrakcyjna dla inwestorów jako środek przechowywania wartości. To sprawia, że szansa na wpadnięcie w pułapkę płynności jest większa, stwarzając bankowi centralnemu poważniejsze ograniczenia w zakresie obniżki realnej stopy procentowej zgodnie z oczekiwaniami uczestników rynku w okresie spowolnienia gospodarczego. Ponadto luzowanie ilościowe może wzmocnić pułapkę płynności poprzez dalsze obniżenie długoterminowej stopy procentowej. Innymi słowy, więcej zastrzyków pieniężnych podczas pułapki płynności może jedynie ją wzmocnić, utrzymując niską stopę inflacji i tym samym realny zwrot z pieniędzy na wysokim poziomie.

Alternatywą dla polityki luzowania ilościowego w sytuacji, gdy gospodarka znajduje się w pułapce płynności, jest niekonwencjonalna polityka pieniężna w postaci tzw. pieniędzy z helikoptera. Chociaż pierwotna koncepcja pieniądza helikopterowego opisuje banki centralne dokonujące płatności bezpośrednio na rzecz osób fizycznych, ekonomiści używają terminu „pieniądze z helikoptera” w odniesieniu do szerokiej gamy różnych pomysłów politycznych, w tym stałej monetyzacji deficytu budżetowego $\mathrm{z}$ dodatkowym elementem w postaci próby zmiany oczekiwań inflacyjnych uczestników rynku. Koncepcja ta często określana jest mianem dywidendy obywatelskiej („Pieniadze zrzucane z helikoptera”, b.d.).

Wyrażenie „pieniądze z helikoptera” zostało po raz pierwszy sformułowane przez Friedmana (1969) w celu zilustrowania skutków ekspansji monetarnej. Pojęcie to zostało ponownie wykorzystane przez ekonomistów jako alternatywna propozycja dla prowadzonej polityki pieniężnej, kiedy to prezes FED zasugerował, że koncepcję pieniędzy z helikoptera można wykorzystać, aby zapobiec deflacji (Rosati, 2016).

Ogólnie rzecz biorąc, ekspansywna polityka pieniężna, w tym polityka luzowania ilościowego i koncepcja pieniędzy z helikoptera obejmują kreację pieniądza przez bank centralny w celu zwiększenia podaży pieniądza. Jednakże wpływ polityki luzowania ilościowego na bilans banku centralnego jest zupełnie inny niż w przypadku koncepcji pieniędzy $\mathrm{z}$ helikoptera. W ramach polityki luzowania ilościowego banki centralne tworzą rezerwy, kupując obligacje lub inne aktywa finansowe, dokonując odwracalnej zamiany posiadanych aktywów. Z kolei w przypadku koncepcji pieniędzy z helikoptera banki centralne rozdają pieniądze bez zwiększania aktywów w swoich bilansach. Ekonomiści twierdzą również, że wpływ jednej i drugiej koncepcji na oczekiwania inflacyjne uczestników rynku jest odmienny. Mianowicie, pieniądze z helikoptera 
prowadzące do wzrostu podaży pieniądza są postrzegane jako bardziej trwałe, czyli w większym stopniu nieodwracalne niż w przypadku polityki luzowania ilościowego. Ekonomiści uważają także, że efekt końcowy obu polityk nie różni się diametralnie od efektu jednocześnie prowadzonej kombinacji ekspansywnej polityki fiskalnej i ekspansywnej polityki pieniężnej.

Dlatego właściwa polityka pieniężna podczas pułapki płynności nie powinna polegać na dalszym zwiększaniu podaży pieniądza ani na obniżaniu stopy procentowej, ale na podnoszeniu oczekiwań inflacyjnych poprzez podnoszenie nominalnej stopy procentowej. W tej sytuacji, jeśli podaż pieniądza spadnie, nominalna stopa procentowa wzrośnie, a inwestorzy będą bardziej skłonni zamienić gotówkę na oprocentowane aktywa. Jeśli popyt na pieniądz obniży się bardziej niż proporcjonalnie w stosunku do spadku podaży pieniądza z powodu presji na wzrost stopy procentowej, inflacja wówczas wzrośnie. Innymi słowy, tylko wtedy, gdy aktywa finansowe staną się bardziej atrakcyjne niż gotówka, ogólny poziom cen w kraju wzrośnie. Oczywiście tego typu pułapka płynności ma miejsce tylko wtedy, gdy gospodarka znajduje się w głębokiej recesji. Jeśli gospodarka nie znajduje się w takiej sytuacji, zastrzyki pieniężne ze strony banku centralnego powinny doprowadzić do wzrostu inflacji, ponieważ niska stopa procentowa zmniejsza skłonność do oszczędzania, zwiększając skłonność do konsumpcji i inwestycji. Jednakże ekspansywna polityka pieniężna jest niezbędna w szczególności wtedy, gdy gospodarka właśnie znajduje się w recesji (Krawczyk, 2013).

Alternatywnym sposobem na wyjście z pułapki płynności jest prowadzenie ekspansywnej polityki fiskalnej, zgodnie z sugestiami Keynesa. Jednak w warunkach wysokiego poziomu długu publicznego, w szczególności w krajach wysoko rozwiniętych gospodarczo, ekspansja fiskalna może być istotnie ograniczona (Szymańska, 2014).

Obserwacja podejmowanych w przeszłości prób wyjścia z deflacji i pułapki płynności, a w szczególności nieefektywnych działań podjętych w Japonii w latach 90. XX w. i w okresie późniejszym pozwala na stwierdzenie, że nadrzędnym warunkiem prowadzenia efektywnej polityki monetarnej jest skuteczne i trwałe pobudzanie oczekiwań inflacyjnych wśród uczestników rynku. Jednocześnie należy podkreślić, iż działania te muszą być wiarygodne w odczuciu przedsiębiorstw i gospodarstw domowych. Ustalenie ścieżki inflacyjnej w postaci odpowiednio szerokiego przedziału umożliwia władzom monetarnym kraju utrwalenie realnej stopy procentowej na ujemnym lub niskim, dodatnim poziomie, w celu stworzenia odpowiednich zachęt do zwiększenia konsumpcji i inwestycji (Frejtag-Mika 2014). 
Z kolei w opinii Svenssona (2001) jedną z metod przywrócenia inflacji może być deprecjacja waluty krajowej. Oprócz zwiększenia inflacji deprecjacja waluty krajowej prowadzi do wzrostu rezerw dewizowych banku centralnego i ogranicza ekspozycję kraju na kolejne zjawiska kryzysowe. Wyjście z pułapki płynności poprzez zwiększenie inflacji w gospodarce ma również swoje uzasadnienie teoretyczne w modelu opracowanym przez Krugmana. Teoretyczny postulat głoszący, że obecna deflacja wymaga w przyszłości inflacji, stwarza podstawę do praktycznych działań w zakresie niekonwencjonalnych posunięć monetarnych. Wykorzystanie przez bank centralny metody luzowania ilościowego prowadzi do wzrostu płynności w systemie finansowym. Jest to użyteczne i powszechnie stosowane narzędzie walki z deflacją, przy czym jednym $\mathrm{z}$ długoterminowych skutków takiego działania jest zagrożenie pojawienia się niekontrolowanej inflacji, co może w dalszej perspektywie okazać się niezwykle szkodliwe dla rozwoju gospodarczego kraju (Frejtag-Mika, 2014).

Jest rzeczą oczywistą, iż wartość pieniądza zmienia się w odmienny sposób w warunkach inflacji i w sytuacji występowania deflacji. Proces kreacji pieniądza fiducjarnego (fiat money) przyczynia się z jednej strony do pobudzenia gospodarki, ale z drugiej strony prowadzi do spadku wartości posiadanych oszczędności do poziomu wynikającego $\mathrm{z}$ uwzględnienia nowego pieniądza w obiegu. Ponadto stosowanie przez rząd fiskalnych programów stymulacyjnych skutkuje wyższym deficytem budżetowym i długiem publicznym, co nieuchronnie prowadzi do wyższej inflacji w przyszłości. O ile samo zwiększenie podaży pieniądza jest działaniem niezbędnym do wyjścia z pułapki płynności, o tyle wielu ekonomistów sugeruje wykorzystanie w celach stymulacyjnych środków publicznych (Roubini, Mihm, 2011). Skutkiem takich działań jest zamiana długu prywatnego na publiczny, pogorszenie sytuacji $w$ finansach publicznych oraz pojawianie się pokusy nadużycia. Słabością proponowanych działań stymulacyjnych w zakresie polityki fiskalnej jest niska efektywność wydatków infrastrukturalnych (Frejtag-Mika, 2014).

\section{Zakończenie}

Ostatnia dekada niskich, nominalnych stóp procentowych i stosunkowo niewielkiej inflacji stwarza nowe wyzwania dla polityki pieniężnej i fiskalnej. Obecne ramy polityki zostały przede wszystkim opracowane w czasach, gdy dolna granica nominalnych stóp procentowych nie stanowiła poważnego problemu dla banków 
centralnych, a uznaniowa polityka fiskalna nie była powszechnie uważana za istotną część polityk stabilizacyjnych (Nakata, Schmidt, 2019).

To, w jaki sposób gospodarka reaguje na pułapkę płynności, w największym stopniu zależy od występującego w kraju poziomu długu publicznego. Jeśli jest on kraju stosunkowo wysoki i zbliża się do górnej dopuszczalnej granicy, wówczas może pojawić się relatywnie mało istotny bodziec w postaci nieznacznego wzrostu wydatków rządowych czy też przedłużonego okresu ekspansywnej polityki pieniężnej. Jeśli natomiast poziom długu publicznego jest stosunkowo niski, wówczas rosnące wydatki rządowe mogą stanowić istotny czynnik stymulowania zagregowanego popytu, w sytuacji gdy gospodarka wpada w pułapkę płynności.

Efektywna strategia wyjścia kraju z pułapki płynności powinna łączyć w sobie kombinację odpowiednio dobranych reform strukturalnych, właściwie prowadzonej polityki fiskalnej i monetarnej. Nie należy również zapominać o ewentualnych działaniach prewencyjnych, które mogą zapobiec wpadnięciu kraju w pułapkę płynności. Chodzi chociażby o takie działania zaradcze jak uzdrowienie systemu bankowego, zwiększenie stopnia regulacji nadzoru finansowego czy wprowadzenie niezbędnych zmian w architekturze światowego systemu finansowego (Frejtag-Mika, 2014).

\section{Bibliografia}

Arias, M. A., Wen, Y. (2014). The Liquidity Trap: An Alternative Explanation for Today's Low Inflation. The Regional Economist, April. Pobrano z https://www.stlouisfed. org/.

Blanchard, O., Cerutti, E., Summers, L. (2015). Inflation and Activity - Two Explorations and their Monetary Policy Implications. IMF Working Paper, 15, 1-28.

Drukpieniadza, parytet złota i recesje. (2012). Pobrano z https://myslnarodowa.wordpress. com/2012/01/27/druk-pieniadza-parytet-zlota-i-recesje (11.02.2020).

Frejtag-Mika, E. (2014). Spór o drogi wyjścia z pułapki płynności i deflacji. Acta Universitatis Lodziensis Folia Oeconomica, 3(303), 91-107.

Friedman, M. (1968). The Role of Monetary Policy. American Economic Review, 58(1), 1-17. Hicks, J. R. (1937). Mr. Keynes and the 'Classics'. Econometrica, 5(2),147-59.

Keynes, J. M. (1936). The General Theory of Employment, Interest, and Money. London: Macmillan.

Koo, R. C. (2011). The world in balance sheet recession: causes, cure, and politics. Real-World Economics Review, 58, 19-37.

Krawczyk, M. (2013). O polityce fiskalnej i pieniężnej w warunkach pułapki płynności. Ekonomista, 4, 475-496. 
Krugman, P. R. (1998). It's Baaack: Japan's Slump and the Return of the Liquidity Trap. Brookings Papers on Economic Activity, 29(2), 137-206.

Moe, T. G. (2013). Marriner S. Eccles and the 1951 Treasury - Federal Reserve Accord: Lessons for Central Bank Independence. Levy Economics Institute of Bard College Working Paper, 747, 1-349.

Nakata, T., Schmidt, S. (2019). Expectations-driven liquidity traps: implications for monetary and fiscal Policy. ECB Working Paper Series, 2304, 1-54. doi: 10.17016/ FEDS.2019.053

Orphanides, A. (2017). The Fiscal-Monetary Policy Mix in the Euro Area - Challenges at the Zero Lower Bound. European Commission Discussion Paper, 060, 1-44. Pobrano z https://dx.doi.org/10.2139/ssrn.2965805

„Pieniądze zrzucane z helikoptera” jako opcja polityki pieniężnej. (2019). Pobrano z https:// www.obserwatorfinansowy.pl (14.10.2019).

Rosati, D. K. (2016). Nowe tendencje w polityce pieniężnej po kryzysie finansowym 2008-2012. Finanse, Rynki Finansowe, Ubezpieczenia, 4, 461-490. doi: 10.18276/ frfu.2016.4.82/1-39.

Roubini, N., Mihm, S. (2011). Ekonomia kryzysu (tłum. R. Mitoraj). (s. 1-371). Warszawa: Wolters Kluwer.

Gerdesmeier, D. (2019). Stabilność cen - dlaczego jest ważna także dla ciebie? Pobrano z https://www.ecb.europa.eu/pub/pdf/other/whypricestability_pl.pdf (30.04.2019).

Svensson, L. O. (2001). The Zero Bound in an Open Economy: A Foolproof Way of Escaping from a Liquidity Trap. Monetary and Economic Studies, 19, 277-312.

Szymańska, A. (2014). Efekty polityki fiskalnej w warunkach niskich stóp procentowych przegląd literatury. Studia Prawno-Ekonomiczne, 93, 331-349.

Thirion, G. (2017). European Fiscal Union: Economic Rationale and Design Challenges. CEPS Working Document, No 01, 1-38.

Tobin, J. (1975). Keynesian Models of Recession and Depression. American Economic Review Papers and Proceedings, 65, 195-202.

Vandenbroucke, F., Luigjes, C., Wood, D., Lievens, K. (2016). Institutional Moral Hazard in the MultiTiered Regulation of Unemployment and Social Assistance Benefits and Activation - A Summary of Eight Country Case Studies, CEPS Special Report, 137, 1-91.

\section{Streszczenie}

Wpadnięcie kraju w pułapkę płynności oznacza brak skuteczności ekspansywnej polityki pieniężnej banku centralnego mającej na celu zwiększenie popytu konsumpcyjnego i inwestycyjnego w kraju. Sytuacja ta wynika z tego, że uczestnicy rynku (gospodarstwa 
domowe i przedsiębiorstwa) zamiast zwiększać popyt, akumulują rosnącą podaż pieniądza w postaci gotówki. Keynes twierdził, że dla gospodarki znajdującej się w pułapce płynności jedynym sposobem na zwiększenie popytu w kraju i na pobudzenie koniunktury gospodarczej jest prowadzenie ekspansywnej polityki fiskalnej w postaci zwiększenia wydatków rządowych lub zmniejszenia podatków.

Celem podjętych badań jest próba wersyfikacji empirycznej hipotezy pułapki płynności w trzech największych gospodarkach na świecie, tzn. w USA, strefie euro i Japonii po kryzysie finansowym z 2008 r. W artykule wykorzystano metodę badawczą opartą na studiach literaturowych z zakresu makroekonomii i finansów oraz metody statystyczne. Wszystkie wykorzystane w pracy dane statystyczne pochodziły z urzędu statycznego Unii Europejskiej - EUROSTAT oraz z bazy statycznej Konferencji Narodów Zjednoczonych do spraw Handlu i Rozwoju - UNSTATS.

SŁoWA KLUCzowe: luka płynności, kryzys finansowy, polityka pieniężna.

\section{Summary}

Falling into the liquidity trap means the lack of effectiveness of the central bank's expansionary monetary policy aimed at the increase in consumption and investment demand of the country. This situation results from the fact that market participants (households and enterprises), instead of increasing demand, accumulate the growing money supply in the form of cash. Keynes argued that for an economy in a liquidity trap the only way to increase demand in the country and to stimulate the economy is to conduct expansive fiscal policy in the form of higher government spending or the reduction in taxes.

The aim of the undertaken research is an attempt to verify the empirical hypothesis of the liquidity trap in the three largest economies in the world, i.e. in the USA, the euro zone and Japan after the 2008 financial crisis. The article uses a research method based on literature studies in macroeconomics and finance as well as statistical methods. All statistical data used in the work came from the statistical office of the European Union EUROSTAT and from the statistical database of the United Nations Conference on Trade and Development - UNSTATS.

KEYwORDs: liquidity gap, financial crisis, monetary policy.

\section{Nota o autorze}

Piotr Misztal - dr hab., prof. UJK, Wydział Prawa i Nauk Społecznych, Uniwersytet Jana Kochanowskiego w Kielcach; główne obszary działalności naukowej: ekonomia i finanse (ekonomia międzynarodowa, makroekonomia, finanse międzynarodowe); e-mail: pmisztal@ujk.edu.pl; ORCID: 0000-0003-2609-3439. 